\title{
Role of Nitrite in Tumor Growth, Symbiogenetic Evolution of Cancer Cells, and China's Successes in the War against Cancer
}

\author{
Kenneth J. Hsu*, Chao S. Huangfu, Min Z. Qin \\ Center for Health and Environmental Engineering, Henan University, Kaifeng, China. \\ E-mail: *Kenjhsu@aol.com
}

Received July 20 ${ }^{\text {th }}$, 2011; revised August 25 ${ }^{\text {th }}$, 2011; accepted September $10^{\text {th }}, 2011$.

\begin{abstract}
Statistics and experiments indicate a correlation between cancer mortality and nitrite in drinking water. Nitrite is a reductant that can deprive a cell of oxygen; it is also an oxidant that can be a substrate in anaerobic ammonium oxidation, the metabolic mode of the anammox bacteria. Eukaryote cells evolved through a fusion of anaerobic and aerobic bacteria. We postulate that an anammox bacterium sought refuge in a fusion with a membrane-bound cluster of aerobic bacteria. While the latter evolved into mitochondria organelles, the former became the nucleus of a prokaryote cell. Eventually, oxidative phosphorilation is the characteristic metabolic pathway of normal eukaryote cells, and we postulate that anammox is the protein-catabolism pathway for cancer cells. The metabolism consumes nitrite and explains thus the link between nitrite and cancer.
\end{abstract}

Keywords: Nitrite, Tomor, Symbiogenetic Evolution

\section{The Nitrite Paradox}

The relation between nitrite and cancer is controversial. Experimental studies evaluated by the Life Science Council of the National Academy of Sciences of the United States and by the Committee of Experts on Health Control of Foodstuffs of the Council of Europe indicated no carcinogenic effect of nitrite [1,2]. Statistical studies in North America and Europe have not yielded a definitive conclusion. The EPA of the United States, followed by the WHO, identified a no-observed-adverse-effect level (NOAEL) of $10 \mathrm{mg} / \mathrm{L}$ nitrate- $\mathrm{N}$, and of $1 \mathrm{mg} / \mathrm{L} \mathrm{ni-}$ trite-N.

Experiments by Russian, Japanese, and Chinese scientists have found rapid proliferation of cancer cells cultured in nitrite solutions [3-10]. Experiments denying a link between nitrite and cancer may have been a misinterpretation of experimental data by scientists who made no distinction between tumor-initiation and tumor-promotion [11]. The statistical data linking cancer to nitrite are even more impressive. After the rapid industrial development of China after 1980, there have been remarkable increases in the annual cancer-mortality rate at places where the nitrite concentration in drinking water has substantially increased [12-17]. The Chinese statis- tics are obvious because of the great local differences in nitrite pollution. In Europe and North America, nitrite pollution is ubiquitous and the differences are less notable.

This paper seeks an explanation of the Chinese observation of a link between nitrite and cancer.

\section{Warburg's Effect}

Gene mutations may have been caused by deletion or insertion of oncogenes. Mutations that lead to malignancy cause "immortality," allowing malignant cells to escape destruction. Eventually cancer cells break free from the tissue of which they are a part; they can grow and multiply without being attached. Malignant cancer cells travel via the bloodstream to start more tumors elsewhere. The process of metastasis is final.

The stem-cell hypothesis postulates that cancer cells are inherited. Stem cells are called to respond to signals to regenerate damaged cells. Only a very few of such are cancerous, but they are able to differentiate into other tumor cells and malignancy.

The origin of cancer is a multi-factorial process. The growth and reproduction of cancer cells depend on metabolism, by which organisms acquire and utilize the 
energy they need for maintenance of life and performance of biologic functions. There are two main ways to generate energy from the catabolism of glucose in human cells in the form of adenosine triphosphate (ATP): oxidative phosphorilation and glycolysis. Normal cells rely on the pathway of the former; oxygen in the blood stream is taken up by the mitochondria organelles in cells, 38 moles of ATP are derived from the oxidation of 1 mole of glucose, yielding a vast amount of energy. The metabolic mode switches to glycolysis at times of oxygen deprivation. Glycolysis is a less effective metabolism, producing only 2 ATP molecules per glucose molecule.

Warburg noted a difference between cancerous and normal cells in the ratio of glycolysis to respiration; cancer cells seem to be adapted to the hypoxic condition inside tumors [18]. He proposed, therefore, that the prime cause of cancer is the replacement of the respiration in normal body-cells by fermentation. The Warburg hypothesis received support when it was noted that cancer cells with dysfunctional mitochondrial function do not respire by oxidative phosphorilation, when glycolysis becomes the energy-producer [19].

Glycolysis can, however, take place under aerobic conditions in cancer cells [20]. The glycolysis mode of metabolism is an expression of dysfunctional mitochondria, and cannot be considered a cause of tumor-initiation or tumor-promotion.

Recent studies noted that oxygen is consumed during transport across the basal membrane to produce anaerobic micro-environment in cancer cells [20]. Warburg could be correct in his postulate that cancer cells grow under locally hypoxia conditions induced by the oxidation of nitrite [18]. Cells with dysfunctional mitochondria normally die, when they are neither protected nor fed. Kremer suggested that the metabolic pathways in cells with dysfunctional mitochondria can be reverted to anaerobic ones [21]. With an inspiration from Matsomoto, I started my search for the ancestry of cancer cells in anaerobic bacteria [22].

\section{Anaerobic Metabolism by Anammox Bacteria}

Anaerobic metabolism is the mode of methanogenic, sulfate-reduction and methylotrophic bacteria; the oxidants are carbonate, sulfate, and methane. Anaerobic ammounium oxidation by nitrite (anammox) is theoretically possible. It was, however, deemed impossible that such a chemical operation could be performed by anaerobic bacteria, until Arnold Mulder detected the reaction in waste-water treatment $[23,24]$. Anammox bacteria, belonging to the group Planctomycetes, were identified by Kuenen and his colleagues in sewage sludge [25]. The overall anammox process consists of the following two denitrification reactions:

Catabolic: $\quad \mathrm{NH}_{4}^{+}+\mathrm{NO}_{2}^{-}=\mathrm{N}_{2}+2 \mathrm{H}_{2} \mathrm{O}$

Anabolic:

$$
\mathrm{CO}_{2}+2 \mathrm{NO}_{2}^{-}+\mathrm{H}_{2} \mathrm{O}=\mathrm{CH}_{2} \mathrm{O} \text { (biomass) }+2 \mathrm{NO}_{3}^{-}
$$

Thus, $\mathrm{NO}_{2}^{-}$is not only the re-acceptor in ammonium oxidation but also the electron donor for $\mathrm{CO}_{2}$.

The prokaryote group Planctomycetes is identifiable by its S16r RNA gene. The anammox bacteria are distinctive for their budding reproduction and cell organization. Being chemo-litho-autotrophic organisms, they gain their energy (reaction (1)) and biomass for cell growth (reaction (2)) from the conversion of the inorganic substrates ammonium and nitrite, while cell carbon is derived from carbon dioxide.

In bio-reactors containing sewage sludge, oxygen is first pumped in for the nitrification of ammonium, before the anammox process starts to de-nitrify and produce lipids to build cells. Planctomycetes cells grow by anaerobic ammonium oxidation and the increase of the biomass has a doubling time of about two weeks [26]. The biomass is decreased when the annamox process is not functioning.

Clusters of Planctomycetes cells are bound by a biomembrane [27]. Nitrite from the oxygen-deficient water of sewage sludge diffuses through the membrane into the cells for the anammox metabolism. The presence of nitrite insures that the micro-chemical environment inside the membrane remains anaerobic. The ammonium produced from the solution of ammonia in a sewage sludge is at first converted to nitrate by the oxygen pumped into a bio-reactor:

$$
\mathrm{NH}_{4}^{+}+2 \mathrm{O}_{2}^{-}=2 \mathrm{H}^{+}+\mathrm{NO}_{3}^{-}+\mathrm{H}_{2} \mathrm{O}
$$

before nitrate is further reduced by ammonium into nitrite (nitrification)

$$
\begin{aligned}
& \mathrm{NH}_{4}^{+}+\mathrm{NO}_{3}^{-}+\mathrm{O}_{2}=2 \mathrm{H}^{+}+2 \mathrm{NO}_{2}^{-}+\mathrm{H}_{2} \mathrm{O} \\
& 2 \mathrm{NH}_{4}^{+}+3 \mathrm{O}_{2}=4 \mathrm{H}^{+}+2 \mathrm{NO}_{2}^{-}+2 \mathrm{H}_{2} \mathrm{O}
\end{aligned}
$$

The oxidant nitrite thus produced by reactions (4) and (5) is the substrate to react with the reductant ammonium for anammox (reaction (1)).

The autotrophic bacteria exist in bioreactors of mixed cultures. Experiments indicate that anammox bacteria metabolize ammonium and nitrite anaerobically. Their cells have an internal anammoxosome compartment [27]. The anammox ability of Planctomycetes is catalyzed by an enzyme (Hydroxylamine oxido-reductase, or HAO) encoded by the S16 rRNA gene. The hydroxylamine oxidoreductase (HAO) is localized within the compartment. 
The anaerobic ammonium oxidation by hydroxylamine is the core of the protein catabolism. Where the catabolic reduction of $\mathrm{NO}^{2-}$ (reaction (1)) is not complete, the products are N20 and NO instead of $\mathrm{N}_{2}$. The anabolic process (reaction (2)) leads to the formation of lipids to build cells.

\section{Nitrosococcus oceani, Urease, and Production of Ammonia}

The complete genome of an anammox bacterium Nitrosococcus oceani has been deciphered. $N$. oceani is identified by its $16 \mathrm{~S}$ rRNA sequencing. The bacterium has all the genes needed for encoding enzymes for anaerobic metabolism [28]. It has the genes to encode two complete terminal cytochrome $\mathrm{C}$ oxididase to gain energy through oxidation of organic matter. It has the genes to encode AMO and PMMO to oxidize ammonia to hydroxylamine and enzyme polyphosphate kinase for glycolysis. It has genes to encode a fructokinase that can make fructose6-phosphate which regulates glycolysis. It has the genes for the ion transport of nitrite imported via format-nitrite (FNT family) or via ammonia/ammonium permease, and for the export of organic and toxic compounds. Most important of all, $N$. oceani has genes to encode enzymes for the hydrolysis of urea to ammonia and $\mathrm{CO}_{2}$, providing thus the cell with the sole source of energy and the reductant ammonium. $N$. oceani does not contain genes that encode subunits of hydrogenase; it cannot depend on $\mathrm{H}_{2} \mathrm{O}$ as the sole source of energy and reductant.

\section{An Evolutionary Theory of Cancer Origin}

The anammox bacteria belong to the most ancient of life forms. The terrestrial atmosphere had no oxygen in the Archaean Era, when anaerobic ammonium-oxidation was a metabolic process that built cells and converted nitrite into the nitrogen of the atmosphere. The anammox bacteria are identifiable by their 16S rRNA gene-a gene that is identified in the genomes of all eukaryotes.

Lynn Margulis proposed that the eukaryotic cell originated from a fusion of an anaerobic and an aerobic bacterium [29]. Kremer presented a hypothesis of metabolism-regression of cancer cells, when he postulated that the cancerous genes are inherited from the anaerobic bacterium [21]. Lane proposed that the invader was an anarchaeon with a genome similar to that of the parasite Rickettsia prowazekii-an aerobic bacterium that used oxygen to generate its energy, and that the host should have been an anaerobic bacterium [30]. Considering the role of nitrite in the growth of tumor cells, I suggest that an anammox bacterium with genes to encode all the enzymes that produce nitrite and ammonium for anaerobic ammonium oxidation was the invader that effected the fusion to produce the first eukaryote cell. A cluster of aerobic bacteria bound by a bio-membrane was the host. The invader evolved into the nucleus, and the aerobic bacteria are changed into the mitochondria of eukaryote cells.

The origin of eukaryotes came after the evolution of photosynthetic bacteria. Some 2.5 billion years ago, oxygen entered into the atmosphere, so that aerobic bacteria flourished. While the global anaerobic environments were being destroyed during the Oxygen Revolution, anaerobic bacteria had to seek refuge in locally anaerobic environments. Where a cluster of aerobic bacteria, in a similar fashion as the anammox Planctomycetes cells [26], is enclosed in a bio-membrane, the micro-environment inside could be nearly anaerobic because of the respiration by the aerobic bacteria. The micro-hypoxic environment became thus the refuge for the anaerobic invader.

Biologic denitrifying activities were once thought to be uniquely characteristic of prokaryotes, before the discovery of the fungal denitrification systems [31]. They are induced under the same conditions as those inducing the bacterial systems, i.e., the presence of nitrite and a low oxygen-fugacity micro-environment that permits anaerobic ammonium oxidation. Nitrite reductase has been detected in the mitochondrial fraction from denitrifying cells. Respiratory substrates such as malate, peruvate and succinate, were effective donors of electrons to these activities in the mitochondrial fractions. Nitrite reduction is coupled to the systems to produce ATP energy.

It was discovered last year that plants also have an anaerobic respiratory system. Plant mitochondria under anaerobic conditions have a capacity to use nitrite as an electron acceptor to generate ATP [32]. Mitochondria isolated from the roots of barley and rice seedlings are capable of oxidizing external NADH and NADPH anaerobically in the presence of nitrite. The rates of anaerobic ATP synthesis are of the same order of magnitude as glycolytic ATP production during anoxia, but are only about $3 \%-5 \%$ of the aerobic mitochondrial ATP synthesis rate.

Adoption of anaerobic ammonium oxidation by animals is yet to be proven. Considering that anammox of eukaryotes was unknown until a few years ago, the possibility is not excluded that this mode of metabolism has been adopted by cancer cells. Like the Planctomycetes cells enclosed in a bio-membrane, cancer cells are also separated by a basement membrane from blood vessels, which are confined to the stromal compartment [20]. Substrates, such as oxygen, nitrites, etc., must diffuse across the membrane. The existence of a $\mathrm{pO}_{2}$ gradient has been detected, and the micro-environment is anaerobic near the oxygen diffusion-limit some $200 \mu \mathrm{m}$ from a vessel wall. There is also a $\mathrm{pH}$ gradient, with $\mathrm{pH}$ de- 
creases from 7.3 to 6.7 in a $400 \mu \mathrm{m}$ distance. The $\mathrm{pH}$ decrease is an indication that the anammox process has become effective in the anaerobic micro-environment of cancer cells, where ammonium is oxidized by nitrite.

It is well known that humans excrete more nitrites and nitrate than they could have ingested from food [33,34]. The presence of intra-cellular nitrites and nitrates, the metabolic products of anammox (reactions (4) and (5)) could be considered an evidence of anammox metabolism by cancer cells. The other substrate ammonium for anammox is provided by the hydrolysis of urea by the enzyme urease; the reaction produces ammonia and $\mathrm{CO}_{2}$ :

$$
\left(\mathrm{NH}_{2} \mathrm{NH}_{2}\right)_{2} \mathrm{CO}+\mathrm{H}_{2} \mathrm{O}=\mathrm{CO}_{2}+2 \mathrm{NH}_{3}
$$

The enzyme urease that promotes the hydrolysis of urea is present both in the genomes of anaerobic bacteria such as $N$. oceani and in cancer patients [35].

Multi-purpose genes in the human genome are overexpressed in cancers. Of these genes, 15 are involved in the protein biosynthesis and folding, six in glycolysis [36]. A comparison of the human cancer genomes with that of $N$. oceani may verify or falsify whether the anammox processes are the metabolic pathways of cancer cells.

In cancer cells, genes for oxidative phosphorilation is deleted or suppressed, replaced by those that encode glycolysis. Even more significant is the observation of the enhanced activities of hydrolysis of urea by the enzyme urease in the metabolism of cancer patients [37]. In our postulate that anammo promotes the tumor growth, ammonium is produced by the hydrolysis of urea for nitrification. This ammonium is then combined with nitrite as the substrates for anammox mode metabolism of cancer cells.

\section{Prevention and Cure of Cancer}

Current cancer researches in the West emphasize the studies of tumor-initiations. The mechanism of gene mutations are unpredictable. The treatments, including surgery, radiation and chemical therapies, remove or exterminate cancer cells. Some cancer drugs or therapies have, however, a function to suppress enzymes such as HAO, AMO, urease, etc that promote cancer-growth.

My hypothesis of symbiogenetic origin of cancer is a chain of facts and postulates linked by speculations: cancer mortality correlates to nitrite in drinking waternitrite is a tumor promoter-glycolysis is prevalent in cancer cells-anaerobic respiration is the metabolic mode of cancer cells-ammonium and nitrite are the substrates for anammox under hypoxic conditions-anammox is the metabolic mode of cancer cells-urease promotes the production of ammonium, which is oxidized in part (during anammox) to form nitrite-suppression of enzymes that produce ammonium and/or nitrite could prevent anammox and thus starve the cancer cells. Cancer research studies could falsify or verify the postulates or speculations to yield new drugs for cancer cure.

The main purpose of this paper is, however, to provide an explanation of the Chinese observation of a link between nitrite and cancer. We believe that China's victorious battles in the War Against Cancer can be explained because their recognition of a link between nitrite and cancer-mortality.

It has been suggested that daily micrograms of nitrite-intake are insufficient to provide the substrate for protein-catabolism to grow cancer cells [38]. However, the role of nitrite in carcinogenesis is probably that of a catalyst to induce hypoxia that triggers the hydrolysis of urea and the ammonium oxidation. It is well known that nitrite in the bloodstream could induce a loss of oxygen, and excessive dose is the cause of methemoglobinemia. C.V. Dang suggested that the role of nitrite-intake is to induce hypoxia [39]. I now believe that the large quantity of nitrite needed for anammox metabolism may have been produced endogenously by the hydrolysis of urea.

Taking seriously the implications of their statistical data, the Chinese Ministry of Health promulgated in 2004 a maximum permissible contamination level (MPCL) of $0.002 \mathrm{mg} / \mathrm{l}$ nitrite nitrogen for "purified clean water," $1 / 500^{\text {th }}$ the NOEAL of the US or of WHO. The Chinese Government has spent billions to switch the sources of drinking water in areas of cancer epidemics: in Henan, Guangxi, Fujien, Tienjien, Jiangsu, etc. The policy has yielded results, and China could claim local victories in the War against Cancer, where the cancer mortality rate has been reduced to half after the switch of the sources of drinking water (see Tables 1 and 2) [8]. The Chinese Government is appropriating, for example, 1.6 billion yuan to provide nitrite-free groundwater for the 3.8 inhabitants

Table 1. Annual esophageal-cancer-mortality (in persons per 100,000) at linzhou county, Henan, China.

\begin{tabular}{cccc}
\hline Year & $\begin{array}{c}\text { Population } \\
\text { sample-size }\end{array}$ & $\begin{array}{c}\text { Incidence } \\
\text { rate }\end{array}$ & $\begin{array}{c}\text { Mortality } \\
\text { rate }\end{array}$ \\
\hline $1959-1963$ & 3 & 9 & 8 \\
$1964-1968$ & 2 & 12 & 1 \\
$1972-1976$ & 3 & 18 & 1 \\
$1977-1980$ & 3 & 12 & 1 \\
$1981-1985$ & 4 & 13 & 1 \\
$1986-1990$ & 4 & 13 & 1 \\
$1991-1995$ & 4 & 11 & 9 \\
$1997-2000$ & 4 & 11 & 8 \\
${ }^{*} 2001-2003$ & 0 & 10 & 8 \\
\hline
\end{tabular}

*Small sample size at the time of completion of the survey. 
Table 2. Annual esophageal-cancer mortality-rate (in persons per 100,000) at 17 townships of Linzhou county, Henan, China, 1964-1974 and 2001-2003.

\begin{tabular}{|c|c|c|c|c|}
\hline Township & $\begin{array}{c}\text { Main } \\
\text { source }\end{array}$ & $\begin{array}{c}\text { Mortality rate } \\
1964-1974\end{array}$ & $\begin{array}{l}\text { Main } \\
\text { source }\end{array}$ & $\begin{array}{c}\text { Mortality } \\
\text { 2001-2003 }\end{array}$ \\
\hline Rencun & $\begin{array}{l}\text { Hongqi } \\
\text { Canal }\end{array}$ & 184 & $\begin{array}{l}\text { Hongqi } \\
\text { Canal }\end{array}$ & 163 \\
\hline Donggang & $\begin{array}{l}\text { Hongqi } \\
\text { Canal }\end{array}$ & 141 & $\begin{array}{l}\text { Hongqi } \\
\text { Canal }\end{array}$ & 145 \\
\hline Shibanyan & $\begin{array}{l}\text { Hongqi } \\
\text { Canal }\end{array}$ & 177 & Mixed & 91 \\
\hline Yaocun & $\begin{array}{l}\text { Hongqi } \\
\text { Canal }\end{array}$ & 171 & Mixed & 118 \\
\hline Lingyang & $\begin{array}{l}\text { Hongqi } \\
\text { Canal }\end{array}$ & 170 & Mixed & 132 \\
\hline Heshun & $\begin{array}{l}\text { Hongqi } \\
\text { Canal }\end{array}$ & 128 & Mixed & 102 \\
\hline Chengguang & $\begin{array}{l}\text { Hongqi } \\
\text { Canal }\end{array}$ & 110 & Groundwater & 90 \\
\hline Chengjiao & $\begin{array}{l}\text { Hongqi } \\
\text { Canal }\end{array}$ & No data & Groundwater & 48 \\
\hline Chengjiao & $\begin{array}{l}\text { Hongqi } \\
\text { Canal }\end{array}$ & 113 & Groundwater & 61 \\
\hline Caishang & $\begin{array}{l}\text { Hongqi } \\
\text { Canal }\end{array}$ & 76 & Groundwater & 32 \\
\hline Hejian & $\begin{array}{l}\text { Hongqi } \\
\text { Canal }\end{array}$ & 81 & Groundwater & 37 \\
\hline Dongyao & $\begin{array}{l}\text { Hongqi } \\
\text { Canal }\end{array}$ & 80 & Groundwater & 38 \\
\hline Guilin & $\begin{array}{l}\text { Hongqi } \\
\text { Canal }\end{array}$ & 95 & Groundwater & 45 \\
\hline Yuankang & $\begin{array}{l}\text { Hongqi } \\
\text { Canal }\end{array}$ & 92 & Groundwater & 77 \\
\hline Cadian & Qi River & 102 & Qi River & 81 \\
\hline Zhexia & Qi River & 89 & Qi River & 81 \\
\hline Linqi & Qi River & 90 & Qi River & 109 \\
\hline
\end{tabular}

of Zhoukou, Henan. To maintain balance of hydrologic budget, the Nation is embarking on a multibillion \$ program of denitritization, using my invention of biologic cleansing by diatoms [40]. We expect to prevent more than half a million cancer deaths in China each year, after the Nation's sources of water supply meet the $0.002 \mathrm{mg} / \mathrm{l}$ nitrite- $\mathrm{N}$ standard recommended by the Chinese Ministry of Health.

\section{Acknowledgements}

We are grateful to James Wang, Nick Lane, David Roger, Graham Shields, Lynn Margulis, Frank Dickson, and Zeng Yi for critical reading of the manuscript. The research is supported by the Center of Health and Environmental
Engineering, Henan University, Kaifeng China.

\section{REFERENCES}

[1] National Academy of Sciences, National Research Council, Life Sciences Council, "The Health effect of Nitrate, Nitrite and N-Nitroso,” National Academy Press, Washington DC, 1981.

[2] Committee of Experts on Health Control of Foodstuffs, "Nitrates and Nitrites in Foodstuffs," Council of Europe Press, Strasbourg, 1993, p. 128.

[3] D. C. Paik, D. V. Saborio, R. Oropeza and H. P. Freeman, "The Epidemiological Enigma of Gastric Cancer Rates in the US," International Journal of Epidemiology, Vol. 30, No. 1, 2001, pp. 181-182. doi:10.1093/ije/30.1.181

[4] Y. Kitamura, T. Umemura, K. Okazaki, et al., "Enhancing Effects of Simultaneous Treatment with Sodium Nitrite on 2-Amino-3-methylimidazo[4,5-f] Quinoline-Induced Rat Liver, Colon and Zymbal's Gland Carcinogenesis after Initiation with Diethylnitrosamine and 1,2Dimethylhydrazine," International Journal of Cancer, Vol. 118, No. 10, 2006, pp. 2399-2404. doi:10.1002/ijc.21649

[5] T. H. Tseng, M. C. Chang, J. D. Hsu, et al., "Tumor Promoting Effect of N-nitroso-N-(2-hexanonyl)-3'-nitrotyramine (a Nitrosated Maillard Reaction Product) in Benzoa Pyrene-Initiated Mouse Skin Carcinogenesis,” ChemicoBiological Interactions, Vol. 115, No. 1, 1998, pp. 23-38. doi:10.1016/S0009-2797(98)00056-8

[6] H. Tsuda and M. Hasegawa, "Malignant Transformation of Mouse BALB/c3T3 Cells Induced by $\mathrm{NaNO}_{2}$," Carcinogenesis, Vol. 11, No. 4, 1990, pp. 595-597. doi:10.1093/carcin/11.4.595

[7] J. Sun, K. Aoki, W. Wang, et al., "Sodium Nitrite-Induced Cytotoxicity in Cultured Human Gastric Epithelial Cells,” Toxicology in Vitro, Vol. 20, 2006, pp. 1133-1138. doi:10.1016/j.tiv.2006.02.005

[8] O. I. Bol'shakova, A. G. Sverdlov and S. I. Timoshenko, "Effect of Nitric Oxide Donor on the Stability of NonTransformed and Malignant Cells to Ultraviolet and Gamma Radiation,” Tsitologia, Vol. 46, 2004, pp. 39-42.

[9] I. V. Kondakova, G. V. Zagrebel'naya and E. T. Choinzonov, "NO-Generating Compounds Modify Tumoritoxic Effect of Doxorubicin,” Bulletin of Experimental Biology and Medicine, Vol. 137, No. 6, 2004, pp. 585-587. doi:10.1023/B:BEBM.0000042719.10494.3f

[10] A. Yoshida, T. Harada and T. Kitazawa, "Effects of Age on Endometrial Carcinogenesis Induced by Concurrent Oral Administration of Ethylenethiourea and Sodium Nitrite in Mice,” Experimental and Toxicologic Pathology, Vol. 48, No. 4, 1996, pp. 289-298. doi:10.1016/S0940-2993(96)80021-2

[11] C. S. Huangfu, K. J. Hsu, M. Z. Qin and T. S. Ma, “The Relationship between Nitrite and Cancer,” Journal of Henan University (Natural Science), Volume for 2009, 2009, pp. 1-5. 
[12] D. Lai, "Geostatistical Analysis of Chinese Cancer Mortality," Journal of Data Science, Vol. 2, 2004, pp. 177193.

[13] Z. X. Xu, "Chemical Fertilizers, Sewage-Treatment and Aesophageal Cancer (in Chinese)," Scientific Publishers, Beijing, 2003, p. 257.

[14] W. Q. Lu, C. L. Chen and W. Z. Li, "Link between Cancer and Drinking Water Quality in Areas of High and of Low Cancer-Incidence,” Cancer in China, Vol. 9, 2000, p. 227.

[15] J. Y. Han, M. X. Wang and Y. Ma, “Cancer Mortality Rate and Nitrite in Drinking Water, Linzhou (Chinese with English Abstract)," Henan Disease Control Medicine, Vol. 11, 2000, pp. 65-69.

[16] X. Deng, C. Q. Lin and Z. G. Gu "Cancer-Mortality Rate of Nitrite in Canton's Drinking Water (Chinese with English abstract)," Physiological Science, Vol. 23, 2004, pp. 38-41.

[17] J. Han, "The Effect of Switching the Source of Drinking Water on the Cancer the Source of Drinking Water on the Cancer-Mortality Rate of Linzhou," Journal of Environment and Health (Beijing), Vol. 22, 2005, pp. 200-202.

[18] O. Warburg, "On the Origin of Cancer Cells," Science, Vol. 123, No. 3191, 1956, pp. 309-314. doi:10.1126/science.123.3191.309

[19] K. Garber, "Energy Boost: The Warburg Effect Returns in a New Theory of Cancer," Journal of National Cancer Institute, Vol. 94, 2004, pp. 1805-1806. doi:10.1093/jnci/96.24.1805

[20] R. A. Gatenby and R. J. Gillies, "Why do Cancers Have High Aerobic Glycolysis,” Nature Reviews Cancer, Vol. 4, 2004, pp. 891-899. doi:10.1038/nrc1478

[21] H. Kremer, "The Silent Revolution in Cancer and AIDS Medicine,” Xlibris Corporation, Zurich, Vol. 633, 2008, p. 71.

[22] K. J. Hsu, P. Matsumoto, W. H. Ye, Y. Zhen, S. X. Lu, J. L. Li and S. Sun, "Nitrite in Drinking Water and Cancer," Scientia Sinica, 2009, In Press.

[23] A. Mulder, “Anoxic Ammonium Oxidation,” US Patent No. 427849, 1992.

[24] A. Mulder, A. A. Graaf, L. Robertson and J. G. Kuenen, "Anaerobic Ammonium Oxidation Discovered in a Denitrifying Fluidized Bed Reactor," FEMS Microbiology Ecology, Vol. 16, No. 3, 1995, pp. 177-184. doi:10.1111/j.1574-6941.1995.tb00281.x

[25] J. G. Kuenen and M. S. M. Jetten, "Extraordinary Anaerobic Ammonium Oxidizing Bacteria,” American Society for Microbiology News, Vol. 67, No. 9, 2001, p.12.

[26] K. Egli, J. R. van der Meer and H. Siegrist, "The Anammox Process for Nitrogen Removal from Waste Water," EAWAG News, Zurich, Vol. 56, 2005, pp. 20-21.

[27] L. van Niftrik, W. J. Geerts, E. G. van Humbel, R. J. Webb, J. A. Fuerst and M. Strous, "Linking Ultrastructure and Function in Four Genera of Anaerobic-Ammonium Oxidation Bacteria,” Journal of Bacteriology, Vol. 190, No. 2, 2008, pp. 708-717. doi:10.1128/JB.01449-07

[28] M. G. Klotz, P. S. G. Chain, A. F. El Sheikh, L. R. Hauser, S. G. Hommes, F. W. Lariomer, S. A. Malfatti, J. M. Norton, A. T. Poret-Peterson, L. M. Vergez and B. B. Ward, "Complete Genome Sequence of Marine Chemolithoautotrphic Amm-OX Bacterium Nitrosococcus oceani," Applied and Environmental Microbiology, Vol. 72, 2006, pp. 6299-6315. doi:10.1128/AEM.00463-06

[29] Sagan and L. Margulis, "On the Origin of Mitosing Cells," Journal of Theoretical Biology, Vol. 14, 1967, pp. 255274.

[30] N. Lane, "Power, Sex, Suicide: Mitochondria and the Meaning of Life,” Oxford University Press, Oxford, 2005, p. 354.

[31] M. Kobayashi, Y. Matsuo, A. Takimoto, S. Suzuki, F. Maruo and H. Shoun, "De-Nitrification, a Novel Type of Respiratory Metabolism in Fungal Mitochondrion,” Journal of Chemical Biology, Vol. 271, No. 27, 1996, pp. 16263-16267. doi:10.1074/jbc.271.27.16263

[32] M. Stoimenova, A. Igamberdiev, K. J. Gupta and R. D. Hill, "Nitrite-Driven Anaerobic ATP Synthesis in Barley and Rice Root Mitochondria,” Planta, Vol. 226, No. 2, 2007, pp. 465-474. doi:10.1007/s00425-007-0496-0

[33] H. H. Mitchell, H. Shoule and H. S. Grindley, "The Origin of Nitrates in Urine,” Journal of Biological Chemistry, Vol. 24, 1916, pp. 461-490.

[34] J. O. Lundberg, J. Weitzberg, J. A. Cole and N. Benjamine, "Nitrate, Bacteria and Human Health," Nature Review/Microbiology, Vol. 2, 2004, pp. 593-602.

[35] S. Ito, T. Kohli, H. Murakita, Y. Ohotaki, T. Azuma and M. Kruiyama, "Differences in Urease Activity in the Live Helicobacter pylori Cultured from Patients with Gastgroduodenal Diseases,” European Journal of Gastroenterology and Hepatology, Vol. 7, 1989, pp. 83-88.

[36] B. Alternberg, C. Gemuend and K. O. Greulich, "Ubiquitous Cancer Genes: Multipurpose Molecules for Protein Micro-Arrays,” Proteomics, Vol. 6, 2007, pp. 67-71. doi:10.1002/pmic.200500154

[37] C. H. Wu, M. Huang, C. S. Yeh, J. W. Wang, T. L. Cheng and S. R. Lin, "Over Expression of Helicobacter Pylori-Associated Urease mRNAs in Human Gastric Cancer,” DNA and Cell Biology, Vol. 2, 2007, pp. 641-648. doi:10.1089/dna.2007.0599

[38] J. Wang, Harvard University, June 2007.

[39] C. V. Dang, D. Dean and J. Hopkins, Medical School, June 2007.

[40] K. J. Hsu, W. H. Ye, Y. H. Kong, D. Li and F. Hu, "Use of Hydrotransistor and Self-Cleaning Pond for De-Nitrification to Produce Purified Non-Carcinogenic Water for Drinking and for Groundwater Recharge,” Technical Report, Tarim Resources Recycling Ltd., Haslemere, 2007. 